\title{
Consumption Time of Captopril Influenced the Outcomes of Patients with Stage 1 Hypertension
}

\author{
Sulastri Herdaningsih ${ }^{1}$, Ahmad Muhtadi $^{2}$, Keri Lestari ${ }^{2}$ \\ ${ }^{1}$ Yarsi Pharmaceutical Academy (Akademi Farmasi Yarsi), Pontianak, West Kalimantan, Indonesia. \\ ${ }^{2}$ Department Pharmacology and Clinical Pharmacy, Faculty of Pharmacy, Universitas Padjadjaran, \\ Jatinangor, West Java, Indonesia.
}

\begin{abstract}
Differences in drugs consumption time may affect its absorption and metabolism in the body which could lead to differences in its efficacy. For hypertension patients, one of the most frequently used drugs for lowering blood is captopril. However, information regarding the influence of consumption time on captopril efficacy was limited. Therefore, this study was conducted to compare the efficacy of captopril in lowering blood pressure when administered before and after meal. This was an experimental study with two treatment groups, conducted at Dr. Soedarso General Hospital, Pontianak, Indonesia, during April-June 2015. Statistical analysis was performed using Mann-Whitney, Exact-Fisher, and T-test. We found out that the reduction of systolic blood pressure in group who consumed captopril before and after meal was $30 \mathrm{mmHg}$ and $25 \mathrm{mmHg}$, respectively $(\mathrm{p}<0.05)$. The similar reduction in diastolic bloos pressure was observed in both groups $(10 \mathrm{mmHg}, \mathrm{p}>0.05)$. In conclusion, it is recommended to take captopril on an empty stomach since it showed better efficacy when administered before meal compared to after meal consumption.
\end{abstract}

Keywords: hypertension, captopril, absorption

\section{Introduction}

Stage 1 hypertension is a disease characterized by systolic blood pressure of $140-159 \mathrm{mmHg}$ and diastolic blood pressure in the range of 90-99 $\mathrm{mmHg}$. The recommended treatment for stage I hypertension include thiazide diuretic drugs, angiotensin converting enzyme inhibitors (ACEI), angiotensin receptor blockers (ARB), beta-blockers (BB), and calcium channel blockers (CCB). One of the most frequently used anti-hypertensive agent is captopril. ${ }^{1,2}$

The timing of drug consumption could significantly affects effectiveness of the treatment. The presence or absence of food in the stomach could affect the absorption of drugs in the body which could lead to differences in its efficacy. The peak effect

Corresponding author: Sulastri Herdaningsih. Yarsi Pharmaceutical Academy (Akademi Farmasi

Yarsi) Pontianak, West Kalimantan, Indonesia. Email : sulastriherdaningsih08@gmail.com 
of captopril is observed after 1-1.5 hours after drug administration and absorption is reduced by $30 \%-40 \%$ in the presence of food. ${ }^{4}$

In Indonesia, West Kalimantan was among in the top lists of provinces with the highest prevalence of hypertension. ${ }^{2}$ Health Minister Decree HK.02.02/Menkes/390/2014 stated that one of the general hospital in Pontianak, Dr. Soedarso General Hospital, was referred as one of the national referral hospital for hypertension. ${ }^{5}$ Based on the field observations conducted at this hospital, most nurses administered captopril after meal. The knowledge of medical staff responsible to administer drugs to patients was limited. Therefore, in this study we aimed to examine the effectiveness of captopril when taken on an empty stomach and after meals.

\section{Methods}

This was an experimental study with two treatment groups, conducted at Dr. Soedarso General Hospital, Pontianak, Indonesia, during April-June 2015. The target population in this study was the stage 1 hypertensive patient who used a single captopril $(10 \mathrm{mg})$ daily on inpatients at Dr. Soedarso General Hospital, Pontianak. This study was approved by ethical committee Universitas Padjadjaran.
Informed consent was obtained from each subject.

Inclusion criteria were:

- Patients with stage 1 hypertension (systolic blood pressure of 140-159 $\mathrm{mmHg}$ /diastolic was 90-99 $\mathrm{mmHg}$ ).

- Patients aged $\geq 18$ years old.

- Received single captopril therapy $12.5 \mathrm{mg}$ during hospitalization.

We excluded patients who consumed drugs that might affect blood pressure (which interacts with captopril), e.g., antacids (moderate), amifostine (moderate), aprotinin (major), and thiazide diuretics (moderate).

General characteristics of subjects, i.e., age and sex were obtained from medical records. Blood pressure was measured before and after the treatment. Statistical analysis was performed using Mann-Whitney, ExactFisher, and T-test

\section{Results and Discussion}

Thirty subjects were included in this study. The majority of the subjects aged more than 55 years old $(73.33 \%)$ (Table 1$)$. Older age is a risk factor for the progression of hypertension due to the increasing of peripheral resistance, sympathetic nerve activity, and decreased

Table 1. Characteristics of particpants

\begin{tabular}{lcc}
\hline & \multicolumn{2}{c}{ Group } \\
\cline { 2 - 3 } Characteristics & After meal consumption & Before meal consumption \\
\cline { 2 - 3 } & $(\mathbf{n}=\mathbf{1 5})$ & $(\mathbf{n}=\mathbf{1 5})$ \\
\hline 1. Sex & $3(20 \%)$ & $4(26 \%)$ \\
Male (\%) & $12(80 \%)$ & $11(74 \%)$ \\
Female (\%) & & \\
\hline 2. Age (years) & $56.3(6.3)$ & $59.3(6.9)$ \\
Mean (SD) & $48-72$ & $50-79$ \\
Range &
\end{tabular}

* Exact-Fisher for sex and T-test for age 
Table 2. Systolic blood pressure on both groups

\begin{tabular}{lccc}
\hline \multirow{2}{*}{ Systolic Blood Pressure } & \multicolumn{2}{c}{ Groups } & \multirow{2}{*}{ P-value* } \\
\cline { 2 - 3 } & Before meal consumption & After meal consumption & \\
\cline { 2 - 3 } & $\mathbf{( n = 1 5 )}$ & $\mathbf{( n = 1 5 )}$ & \multirow{2}{*}{0.653} \\
\hline Initial (mmHg) & $152.1(3.2)$ & $151.2(4.2)$ & \\
Mean (SD) & 150 & 150 & \\
Median & $150-158$ & $145-158$ & \multirow{2}{*}{$0.003^{*}$} \\
Range & $127.3(8)$ & $118(4.1)$ & \\
\hline End (mmHg) & 130 & 120 & $0.005^{*}$ \\
Mean (SD) & $120-140$ & $110-120$ & \\
Median & $24.7(7.3)$ & $33.2(6)$ & \\
Range & 25 & 30 & $0.001^{*}$ \\
\hline$\Delta$ (mmHg) & $10-35$ & $25-45$ & \\
Mean (SD) & & & \\
Median & $16.3(4.8)$ & $21.9(3.6)$ & \\
\hline \% reduction & 16.1 & 20 & \\
Mean (SD) & $6.7-22.6$ & $17.2-29$ & \\
Median & & & \\
Range & & & \\
\hline
\end{tabular}

*) Mann-Whitney test

sensitivity of baroreceptor reflexes that are important in the regulation of blood pressure. ${ }^{6}$

Majority of the subjects (76.66\%) were elderly women. The risk of hypertension in women would increase after menopause, indicating the major role of the presence of the estrogen hormone in blood pressure regulation. It can increase the level of high density lipoprotein which prevents the occurrence of the process of atherosclerosis which could lead to high blood pressure. ${ }^{7}$

Efficacy of drugs can be influenced by consumption time of drugs. Administration of drugs with food may reduce, delay, increase, or have no effect on drug absorption. Food can affect GI physiological factors such as gastric emptying time, acid secretion, blood flow, intestinal motility, bile and enzyme secretion. $^{8-12}$

The effectiveness of captopril was assessed by evaluating the difference $(\Delta)$ of systolic blood pressure (SBP) and diastolic blood pressure (DBP) in $\mathrm{mmHg}$ units seen from the median values. We found out that the reduction of SBP in group who consumed captopril on an empty stomach and after meal was $30 \mathrm{mmHg}$ and $25 \mathrm{mmHg}$, respectively $(p<0.05)$. The similar reduction in DBP was observed in both groups ( $10 \mathrm{mmHg}, \mathrm{p}>0.05)$.

In the group who took captopril on an empty stomach, the reduction of SBP and DBP were $30 \mathrm{mmHg}$ (20\% reduction) and $10 \mathrm{mmHg}$ $(11.1 \%)$, respectively. In the group who took captopril after meal, the reduction of SBP and DBP were $25 \mathrm{mmHg}(16.1 \%)$ and $10 \mathrm{mmHg}$ $(11.1 \%)$, respectively (Table 2 and 3 ).

The target of SBP and DBP in uncomplicated hypertensive patients (without diabetes mellitus and chronic renal failure) aged $\geq 60$ years are $<150 / 90 \mathrm{mmHg}$. In hypertensive patients with diabetes and chronic kidney 
Table 3. Diastolic blood pressure on both groups

\begin{tabular}{|c|c|c|c|}
\hline \multirow{3}{*}{ Diastolic Blood Pressure } & \multicolumn{2}{|c|}{ Groups } & \multirow{3}{*}{ P-value* } \\
\hline & Before meal consumption & After meal consumption & \\
\hline & $(n=15)$ & $(n=15)$ & \\
\hline \multicolumn{4}{|l|}{ Initial $(\mathrm{mmHg})$} \\
\hline Mean (SD) & $94.7(5.2)$ & $92(5.6)$ & 0.285 \\
\hline Median & 90 & 90 & \\
\hline Range & $90-100$ & $80-100$ & \\
\hline \multicolumn{4}{|l|}{ End (mmHg) } \\
\hline Mean (SD) & $82(4.1)$ & $79.3(2.6)$ & 0.250 \\
\hline Median & 80 & 80 & \\
\hline Range & $80-90$ & $70-80$ & \\
\hline \multicolumn{4}{|l|}{$\Delta(\mathrm{mmHg})$} \\
\hline Mean (SD) & $12.7(4.6)$ & $12.7(4.6)$ & 1.000 \\
\hline Median & 10 & 10 & \\
\hline Range & $10-20$ & $10-20$ & \\
\hline \multicolumn{4}{|l|}{$\%$ reduction } \\
\hline Mean (SD) & $13.3(4.2)$ & $13.6(4)$ & 0.412 \\
\hline Median & 11.1 & 11.1 & \\
\hline Range & $10-20$ & $11.1-20$ & \\
\hline
\end{tabular}

*) Mann-Whitney test

disease, blood pressure should be $<140 / 90$ mmHg. ${ }^{1}$ In this study, the target blood pressure was hardly achieved in group who took captopril after meal. In contrast, target blood pressure was achieved in several subjects from the group who took captopril on an empty stomach.

Previous study showed that the presence of food significantly affects the bioavailability of captopril until 40\%. Current study determined whether the reduction in captopril bioavailability influence its clinical effect on lowering blood pressure. We found out that captopril time consumption significantly affect the blood pressure, particularly SBP. The roles of health care professionals, such as pharmacists, are crucial to ensure the appropriate method of drugs consumption was used to optimize therapeutic effect of the drugs. ${ }^{13}$

Limitation of this study included the absence of the monitoring of dietary intake and level of stres which could influence blood pressure. However, in this study, we already excluded patients who had complications to reduce bias.

\section{Conclusion}

The reduction of blood pressure was higher in subjects who took captopril on an empty stomach. Therefore, it is recommended to take captopril on an empty stomach since it showed better efficacy compared to after meal consumption.

\section{Acknowledgement}

None declared.

\section{Funding}

This research was not funded by any source of grants.

\section{Conflict of Interest}

The authors declared no potential conflicts 
of interest with respect to the research, authorship, and/or publication of this article.

\section{References}

1. Jackson JH, Sobolski J, Krienke R, Wong KS, French-Tamas F, Nightengale B. Blood pressure control and pharmacotherapy patterns in the United States before and after release of the Joint National Committee on prevention, detection, evaluation and treatment of high blood pressure (JNC 7) guidelines. Journal of American Board of Family Medicine. 2008;21:512-521.

2. Hernandez-Vila E. A Review of the JNC 8 Blood Pressure Guideline. Texas Heart Institute Journal. 2015;42(3):226-228.

3. Hussain MA, Mamun AA, Reid C, Huxley RR. Prevalence, awareness, treatment and control of hypertension in Indonesian adults aged $\geq 40$ years: findings from the Indonesia family life survey (IFLS). PLoS ONE. 2016;11(8):16-22.

4. Al-hussain F, Hussain MS, Molina C. Does the sex of acute stroke patients influence the effectiveness of rt-PA?. BMC Neurology. 2014;14:60.

5. Hall JE, Granger JP, do Carmo JM, da Silva AA, Dubinion J, George E. Hypertension: physiology and pathophysiology. Comprehensive Physiology. 2012;2(4):2393-442.

6. Howard VJ, Woolson RF, Egan BM. Prevalence of hypertension by duration and age at exposure to the stroke belt. Journal of the American Society of Hypertension. 2010;4(1):32-41.
7. Cushman M, Cantrell RA, McClure LA. Estimated 10-year stroke risk by region and race in the United States: geographic and racial differences in stroke risk. Annals of Neurology. 2008;64(5):507513.

8. Abuhelwa AY, Williams DB, Upton RN, Foster DR. Food, gastrointestinal $\mathrm{pH}$, and models of oral drug absorption. European Journal of Pharmaceutics and Biopharmaceutics. 2017;112:234-248.

9. Lin L, Wong $H$. Predicting oral drug absorption: mini review on physiologically-based pharmacokinetic models. Pharmaceutics. 2017;9(4):41.

10. Benedetti MS, Whomsley R, Poggesi I, Cawello W. Drug metabolism and pharmacokinetics. Drug Metabolism Reviews. 2009;41(3):344-90.

11. Rizos CV, Elisaf MS. Antihypertensive drugs and glucose metabolism. World Journal of Cardiology. 2014;6(7):517530.

12. Zisaki A, Miskovic L, Hatzimanikatis V. Antihypertensive drugs metabolism: an update to pharmacokinetic profiles and computational approaches. Current Pharmaceutical Design. 2015;21(6):806822.

13. Sumaryono B, Moektiwardoyo M, Yulianto A. Diabetes patients perceptions on drugs consultation program by pharmacists. Pharmacology and Clinical Pharmacy Research. 2016;1(3):86-90. 